\title{
Late Pleistocene Climatic Changes in Central Brazil Indicated by Freshwater Sponges
}

\author{
Vanessa de Souza Machado', Cecilia Volkmer-Ribeiro², Roberto Iannuzzi ${ }^{3}$ \\ ${ }^{1}$ Programa de Pós-graduação em Geociências, Instituto de Geociências, Universidade Federal do Rio Grande do \\ Sul (UFRGS), Porto Alegre, Brasil \\ ${ }^{2}$ Museu de Ciências Naturais (MCN), Fundação Zoobotânica do Rio Grande do Sul (FZB), Porto Alegre, Brasil \\ ${ }^{3}$ Departamento de Paleontologia e Estratigrafia, Instituto de Geociências, UFRGS, Porto Alegre, Brasil \\ Email: biologavsm@gmail.com, cvolkmer1427@gmail.com, roberto.iannuzzi@ufrgs.br
}

Received 9 May 2014; revised 5 June 2014; accepted 1 July 2014

Copyright (C) 2014 by authors and Scientific Research Publishing Inc.

This work is licensed under the Creative Commons Attribution International License (CC BY).

http://creativecommons.org/licenses/by/4.0/

(c) (i) Open Access

\section{Abstract}

The Cemitério Palaeolake deposit in Catalão, Goiás State, Brazil, comprises a single, complete lacustrine sequence, dated from less than $27,500 \pm 4000 \mathrm{yr}$ B.P. to more than $51,780 \pm 400{ }^{14} \mathrm{C}$ yr B.P. The unprecedented presence of spongillite and diatomite layers in this deposit was investigated using spicules of continental sponges as proxy data for environmental and climate reconstruction, which was relatively extensive for the ages examined. From the analysis of the sedimentary features and the associations of spicules preserved in the deposit, it was possible to reconstruct the evolution of the limnic system. Five developmental stages were thus identified, corresponding to the installation (lotic and erosion phase), establishment and development of the lake and its colmatation, the latter correlating to the Last Glacial Maximum (LGM). Moreover, based on the ecological requirements of the sponge species identified in the deposit, it was possible to infer the likely weather patterns related to respective phases of the lake. The presence of the sponge species Corvoheteromeyenia australis, presently recorded only from southern South America, indicated that polar incursions originating from the Antarctic were frequent during the last glacial period and might have played a notable role in what is now central Brazil. However, for a short time, drier and hotter weather conditions might have predominated, as suggested by the presence of the species Corvomeyenia thumi.

\section{Keywords}

Spongillites, Lacustrine Palaeoenvironment, Palaeoclimate, Central Brazil, Late Pleistocene

\section{Introduction}

Palaeoenvironmental and palaeoclimatic reconstructions of the Late Pleistocene, particularly in the central re-

How to cite this paper: Machado, V.S., Volkmer-Ribeiro, C. and lannuzzi, R. (2014) Late Pleistocene Climatic Changes in Central Brazil Indicated by Freshwater Sponges. International Journal of Geosciences, Irvine, Vol. 5, NO. 8, 799-815.

http://dx.doi.org/10.4236/ijg.2014.58071 
gion of Brazil, have been proposed based on the analyses of lake sediments containing pollen, spores and microalgal spectra [1]-[8]. However, several worldwide reports produced on lentic quaternary sediments suggest the use of freshwater sponge spicules as a diagnostic tool in palaeo interpretations [9]-[13]. In this respect, extensive studies have been conducted in South America [14]-[18].

Spongillites and diatomites are evidences that natural environmental conditions can maximize the production of aquatic organisms with silicious supporting structures and generate large deposits of biosilicious rocks, formed in the case of the spongillites from sponge spicules [11] [19], and in that diatomites from diatoms frustules [20] [21]. Studies on these deposits, particularly in freshwater lentic environments, are typically rare, although they have indicated their unique and preferred characteristics in relation to various contexts, including geomorphology [22]-[27], palaeoenvironment [19] [22] [26]-[28], palaeoclimate [19] [27] [29], and, in the case of diatomite, even orbitals [30]. However, to date, deposits of diatomites and spongillites have not been recorded in the same basin.

The Cemitério Palaeolake deposit in Catalão, Goiás State, Brazil was dated from less than 27,500 $\pm 4000 \mathrm{yr}$ BP to more than $51,780 \pm 400{ }^{14} \mathrm{C}$ yr BP [31] [32]. It therefore constitutes the oldest dated deposit in central Brazil, where few such deposits are dated at over 40,000 yr BP [1]-[8]. The study of the Cemitério Palaeolake has revealed the occurrence of facies rich in sponge spicules [31], and fully preserved gemmules [32] produced by the same sponge community related to the spongillite deposits [19] and currently typical of lakes in the Cerrado Biome [33] [34], Metania spinata (Carter, 1881), Dosilia pydanieli Volkmer-Ribeiro (1992), Heterorotula fistula Volkmer-Ribeiro and Motta (1995), Corvomeyenia thumi (Traxler, 1895), Radiospongilla amazonensis Volkmer-Ribeiro and Maciel (1983) and Trochospongilla variabilis Bonetto and Ezcurra de Drago (1973), but added also Corvoheteromeyenia australis (Bonetto and Ezcurra de Drago, 1966). Machado and colleagues [31] also detected rare spicules from species more typical of lotic environments in the Cemitério Palaeolake, including Corvospongilla seckti Bonetto and Ezcurra Drago (1966), Oncosclera navicella (Carter, 1881) and Eunapius fragilis (Leidy, 1851).

However, the Cemitério Palaeolake is remarkable because of its intercalated facies of spongillites and diatomites. Thus, this paper examines the environment related to the formation of these two bio-siliceous deposits, as well as their relationship with the other facies in the palaeolake, extracting from these analyses palaeoenvironmental and palaeoclimatic interpretations that are unprecedented for the ages obtained.

\section{Study Area}

The Cemitério Palaeolake outcrop $\left(18^{\circ} 08^{\prime} \mathrm{S} ; 47^{\circ} 08^{\prime} \mathrm{W}\right)$ is constituted by a continuously exposed lacustrine deposit, formed in a depression at the northern part of the Catalão I Carbonatite Complex (Figure 1). The sedimentary rocks lie discordantly on the dome of magmatic carbonatite [35]. The outcrop consists of a $27 \mathrm{~km}^{2}$ sub-circular plateau, with the NS and EW axes measuring 6 and $5.5 \mathrm{~km}$, respectively. The average elevation is $900 \mathrm{~m}$, rising $100 \mathrm{~m}$ above the surrounding land.

The rocks of the Catalão region are included in the igneous province of the Upper Paranaíba, lying between the Paraná and São Francisco basins [36] [37] (Figure 1). In this same region is an elongated structure extending NW-SE, known as the Upper Paranaíba Arch, in which uplifting began in the early Cretaceous and intensified during the late Cretaceous. This igneous basin was established as a result of intense mafic-ultramafic alkaline and ultrapotassic magmatism generating intrusive (dikes, pipes, diatremes, and plutonic complexes) and extrusive (lava and pyroclastic) bodies. According to Gibson and colleagues [36], the alkaline rocks in this province include, among others, kamafugites, kimberlite, lamproite, and carbonatite complexes. The carbonatite complexes of the Upper Paranaíba include Catalão I and II at the northernmost end of the Province in the state of Goiás and Salitre I and II, Araxá, Tapira, and Serra Negra in the state of Minas Gerais (Figure 1). Of particular note is the Serra Negra dome, which contains a lake of the same name and a rich current deposit of sponge spicules in the bottom sediments [34].

Sand lenses of Layer \# 16 from Section 2, upper interval of the Cemitério Palaeolake outcrop, have previously been dated using thermo-luminescence (TL) and optically stimulated luminescence (OSL) [31]. The TL resulted in an age of 34,700 $\pm 5000 \mathrm{yr}$ BP, whereas that obtained using OSL was 27,500 $\pm 4000 \mathrm{yr}$ BP. Radiocarbon dating of the basal-most layer (Layer \# 5 from Section 1) indicated an age of more than 53,780 years ${ }^{14} \mathrm{C} \mathrm{yr} \mathrm{BP}$ for a fragment of fossil wood and 51,780 $\pm 400{ }^{14} \mathrm{C}$ yr BP for a fern frond [32]. In addition to these, in layer subsequent to the base (Layer \# 2 from Section 2), radiocarbon dating of an angiosperm leaf obtained an age from 48,333 \pm 400 years ${ }^{14} \mathrm{C}$ yr BP [32] (Figure 1 and Figure 2). 


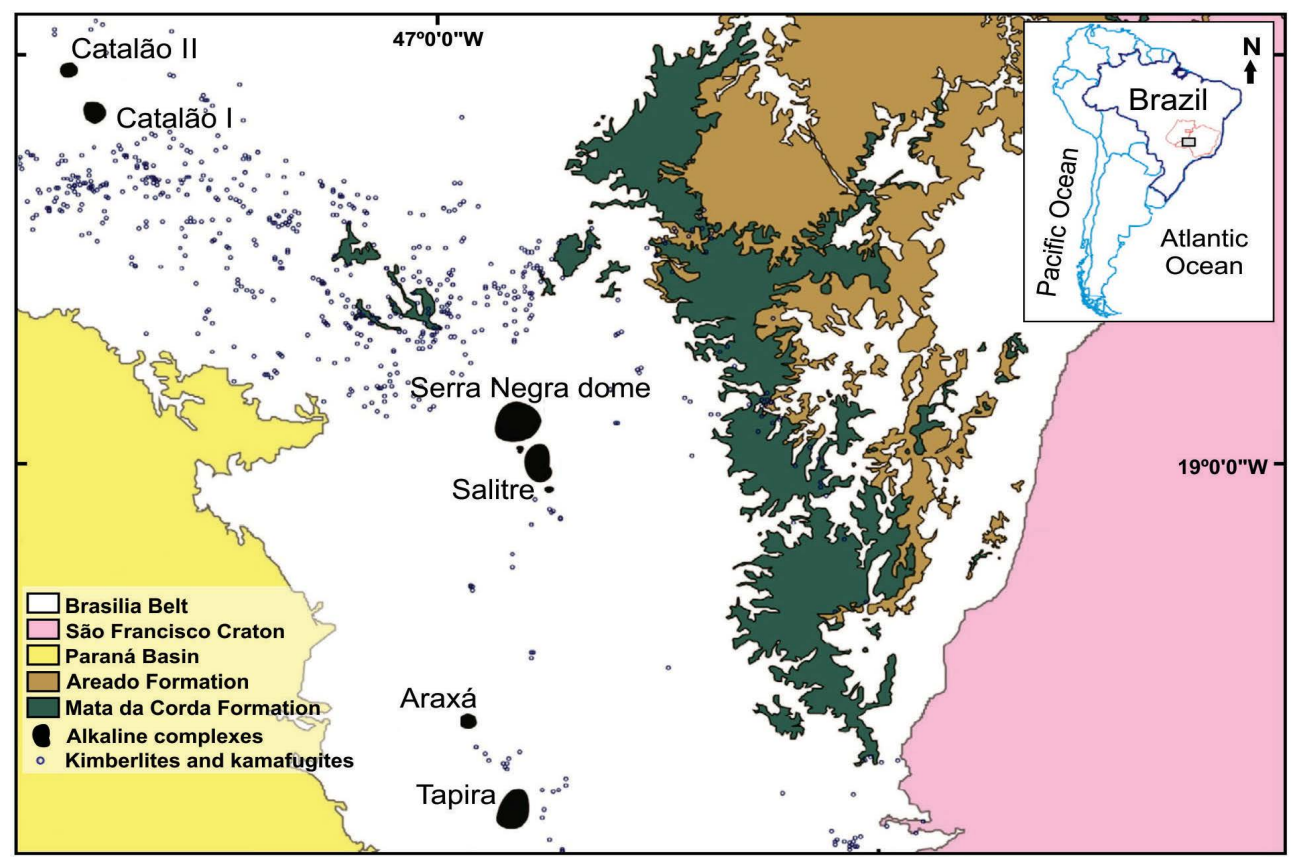

Figure 1. Geological map of the Alto Paranaíba Igneous Province, signaling the alkaline-carbonatite plutonic complex of Catalão I (Catalão, Goiás, central Brazil). Adapted from [37].

\section{Materials and Methods}

Samples removed from each of the 21, 19, and 13 layers of Sections 1, 2, and 3, respectively, were deposited and catalogued in the Porifera Collection of Museu de Ciências Naturais da Fundação Zoobotânica do Rio Grande do Sul (MCN/FZB) under numbers MCN-POR nr 8147 to 8200 [31]. Permanent slides were produced and mounted for taxonomic identification of the sponge spicules following as in [38].

Fragments of the spongillites and diatomites from the Palaeolake were also mounted on supports and placed in a SEM (Philips Model XL20) at the Centro de Microscopia da Universidade Luterana do Brasil (ULBRARS). All the SEM supports containing the studied materials were then included in the respective previously catalogued materials. The presence of abundant sponge gemmoscleres was detected and identified using optical microscopy to examine the permanent slides catalogued in the MCN. The specific identifications were made according to [31] [32]. Drawings of the gemmoscleres were prepared using Camera Clara to illustrate the different species identified. These new analyses allowed us to refine the relative quantification proposed by [31] by differentiating the facies formed by spicules from the sponge skeletons from others containing, in addition, the spicules of the gemmules.

All the layers/sediments obtained from the Cemitério Palaeolake sections were classified according to both the particle size and organic matter (OM) content at the Centro de Estudos Costeiros e Oceanográficos da Universidade Federal do Rio Grande do Sul (CECO-UFRGS). To establish particle size, the coarse sediments were separated using a set of 1-mm Ø sieves [39] [40]; whereas for fine sediments, the small particle sedimentation method in a liquid medium, according to [41] was used. These results were compared to the descriptions of these same layers performed in situ [42]. This allowed us to pinpoint facies containing clasts and thus propose the precise textural classification of each layer from the Cemitério Palaeolake. The combustion-based OM elimination method was used [43] to determine the OM content in the fine sediments (silt and clay). Layer \# 14 from Section 1 and Layers \# 12 and \# 15 from Section 2 had previously been analysed for particle size and OM content [32].

\section{Results}

\subsection{Textural Classification}

The result of the granulometric analysis and the corresponding textural classification of the facies from each of 


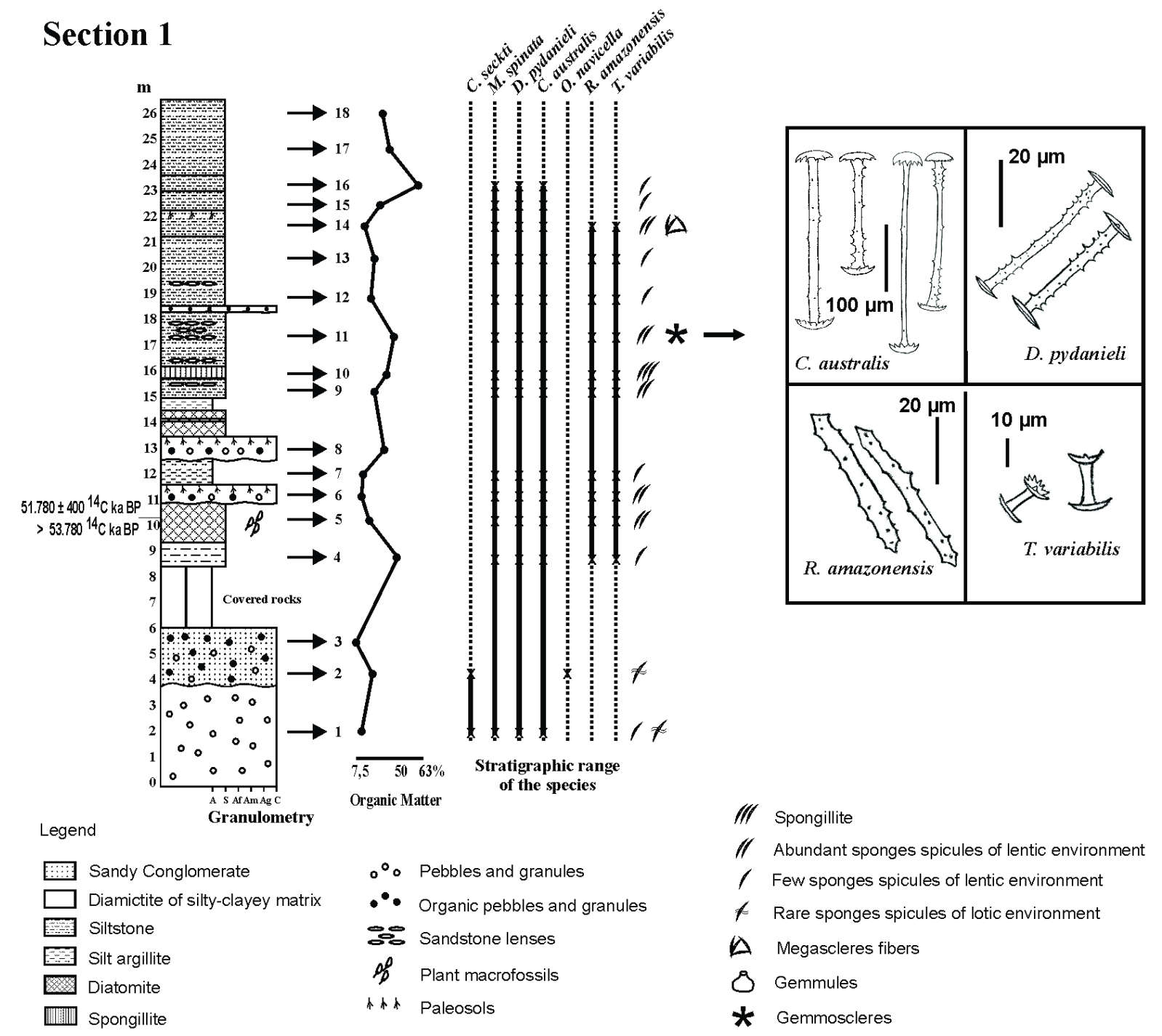

Figure 2. Profile of Section 1 (meters) illustrating from left to right: the results of the textural classification; the percentage of organic matter; the occurrence of the spicules of each sponge species, according to their category and abundance; figures of the gemmoscleres with occurrence in this section. Abbreviations: A, argillite; S, siltstone; Af, fine sandstone; Am, medium sandstone; Ag, coarse sandstone; C, conglomerate/diamictite. Adaptated from [31] [32].

the three sections taken from the Cemitério Palaeolake is shown in Table 1 and illustrated in the distinct profiles shown in Figures 2-4. The ternary diagram in Figure 5 shows that most of the facies from the palaeolake were formed from a fine matrix in the silt fraction, including those layers presenting clasts (Table 1). The latter were classified as diamictites (Layer \# 1, 6 and 8 from Section 1; Layers \# 1, 5, 7, 11 and 14 from Section 2; Layers \# 2, 3, 5/6 and 12/13 from Section 3). Only Layer \# 2/3 from Section 1 presented higher percentages of sand, and was thus classified as a sandy conglomerate. Two layers presented higher percentages of clay and were classified as silt-mudstone, Layer \# 7 from Section 1 and Layer \# 10 from Section 3. In contrast, most of the facies from the palaeolake showed higher percentages of silt and were thus characterized as siltstones (Layers \# 4, 9, 11, 12/13, 14, 15, 16 and 17/18 from Section 1; Layers \# 2, 3, 4, 6, 8, 9, 10, 12 and 13 from Section 2; Layers \# 1 and 11 from Section 3).

The layers formed predominantly of sponge spicules and others formed by diatom frustules, respectively spongillites and diatomites occurred in three Sections of the Cemitério Palaeolake (Table 1, Figures 2-4). The spongillites were identified in Layer \# 10 from Section 1, Layer \# 15 from Section 2, and Layer \# 8 (Figure 6(a), Figure 6(b)) from Section 3. Whilst the diatomites occurred in Layer \# 5 from Section 1, Layer \# 16 from 
Table 1. Results of the sedimentologic analysis of the layers of the Sections 1, 2 and 3 of the Cemitério Palaeolake, Catalão, GO: Organic matter $(\mathrm{OM})$ and Granulometry (Gravel: absent $=0$, minerals clasts $=1$, organic clasts $=2$ ). The results allowed the proposal of the textural classification for each layer.

\begin{tabular}{|c|c|c|c|c|c|c|}
\hline \multirow{2}{*}{ Layers } & \multirow{2}{*}{ OM (\%) } & \multicolumn{4}{|c|}{ Granulometry } & \multirow{2}{*}{ Textural classification } \\
\hline & & Gravel & Sandy (\%) & Silty (\%) & Clay (\%) & \\
\hline \multicolumn{7}{|c|}{ Section 1} \\
\hline 1 & 12.40 & 1 & 17.15 & 64.05 & 18.80 & Diamictite of silty matrix \\
\hline 2 & 21.70 & 1,2 & 57.41 & 31.83 & 7.30 & \multirow{2}{*}{ Sandy Conglomerate } \\
\hline 3 & 7.50 & 1,2 & 34.06 & 25.74 & 25.87 & \\
\hline 4 & 44.90 & 0 & 0.24 & 92.00 & 7.97 & Siltstone \\
\hline 5 & 19.10 & 0 & 0.20 & 54.34 & 45.45 & Diatomite \\
\hline 6 & 12.50 & 1,2 & 0.21 & 63.00 & 36.79 & Diamictite of silty-clayey matrix \\
\hline 7 & 13.70 & 0 & 0.22 & 41.00 & 58.78 & Silty argillite \\
\hline 8 & 32.60 & 1,2 & 21.34 & 65.36 & 13.30 & Diamictite of silty matrix \\
\hline 9 & 23.60 & 0 & 0.11 & 78.61 & 21.28 & Siltstone \\
\hline 10 & 34.20 & 0 & 0.19 & 83.31 & 16.50 & Spongillite \\
\hline 11 & 41.10 & 0 & 0.03 & 88.65 & 11.32 & Siltstone \\
\hline 12 & 20.20 & 0 & 0.24 & 80.11 & 19.65 & \multirow{2}{*}{ Siltstone } \\
\hline 13 & 23.80 & 0 & 0.23 & 80.45 & 19.32 & \\
\hline 14 & 15.30 & 0 & 0.51 & 73.30 & 26.19 & Siltstone \\
\hline 15 & 29.20 & 0 & 0.73 & 83.79 & 16.14 & Siltstone \\
\hline 16 & 62.10 & 0 & 0.19 & 85.94 & 13.87 & Siltstone \\
\hline 17 & 37.00 & 0 & 0.11 & 84.05 & 15.84 & \multirow{3}{*}{ Siltstone } \\
\hline 18 & 26.80 & 0 & 0.10 & 70.52 & 29.37 & \\
\hline & & & & Section 2 & & \\
\hline 1 & 10.65 & 1 & 15.41 & 61.93 & 22.66 & Diamictite of silty-clayey matrix \\
\hline 2 & 32.50 & 0 & 0.28 & 76.15 & 23.57 & Siltstone \\
\hline 3 & 19.90 & 0 & 0.32 & 73.66 & 26.02 & Siltstone \\
\hline 4 & 38.95 & 0 & 0.22 & 86.27 & 13.50 & Siltstone \\
\hline 5 & 41.70 & 1,2 & 0.85 & 82.28 & 16.87 & Diamictite of silty matrix \\
\hline 6 & 37.50 & 0 & 0.19 & 83.32 & 16.49 & Siltstone \\
\hline 7 & 36.60 & 1,2 & 0.49 & 81.56 & 17.95 & Diamictite of silty matrix \\
\hline 8 & 75.60 & 0 & 0.41 & 90.10 & 9.48 & Siltstone \\
\hline 9 & 28.50 & 0 & 0.41 & 77.73 & 21.85 & Siltstone \\
\hline 10 & 48.80 & 0 & 0.95 & 90.64 & 8.41 & Siltstone \\
\hline 11 & 34.15 & 1,2 & 0.25 & 82.21 & 17.54 & Diamictite of silty matrix \\
\hline 12 & 29.70 & 0 & 0.15 & 75.68 & 24.17 & Siltstone \\
\hline 13 & 56.70 & 0 & 1.03 & 87.93 & 11.03 & Siltstone \\
\hline 14 & 21.30 & 1,2 & 0.26 & 71.32 & 28.41 & Diamictite of silty-clayey matrix \\
\hline 15 & 34.05 & 0 & 0.90 & 80.34 & 18.76 & Spongillite \\
\hline \multirow[t]{2}{*}{16} & 30.55 & 0 & 0.02 & 73.20 & 26.78 & Diatomite \\
\hline & & & & Section 3 & & \\
\hline 1 & 28.95 & 0 & 0.36 & 76.46 & 23.18 & Siltstone \\
\hline 2 & 09.65 & 2 & 4.01 & 51.39 & 44.60 & Diamictite of silty-clayey matrix \\
\hline 3 & 17.05 & 2 & 11.01 & 69.51 & 19.48 & Diamictite of silty-clayey matrix \\
\hline 4 & 24.25 & 0 & 0.11 & 70.68 & 29.20 & Diatomite \\
\hline 5 & 11.25 & 2 & 9.95 & 68.44 & 21.61 & \multirow{2}{*}{ Diamictite of silty-clayey matrix } \\
\hline 6 & 13.35 & 2 & 5.82 & 68.99 & 25.18 & \\
\hline 7 & 23.40 & 0 & 0.16 & 68.97 & 30.87 & Diatomite \\
\hline 8 & 33.25 & 0 & 0.02 & 82.88 & 17.10 & Spongillite \\
\hline 9 & 28.05 & 0 & 0.29 & 62.69 & 37.02 & Diatomite \\
\hline 10 & 13.75 & 0 & 0.16 & 47.81 & 52.03 & Silty argillite \\
\hline 11 & 16.85 & 0 & 0.13 & 69.20 & 30.67 & Siltstone \\
\hline 12 & 30.75 & 2 & 0.03 & 84.67 & 15.30 & \multirow{2}{*}{ Diamictite of silty matrix } \\
\hline 13 & 28.50 & 2 & 0.68 & 74.08 & 25.24 & \\
\hline
\end{tabular}




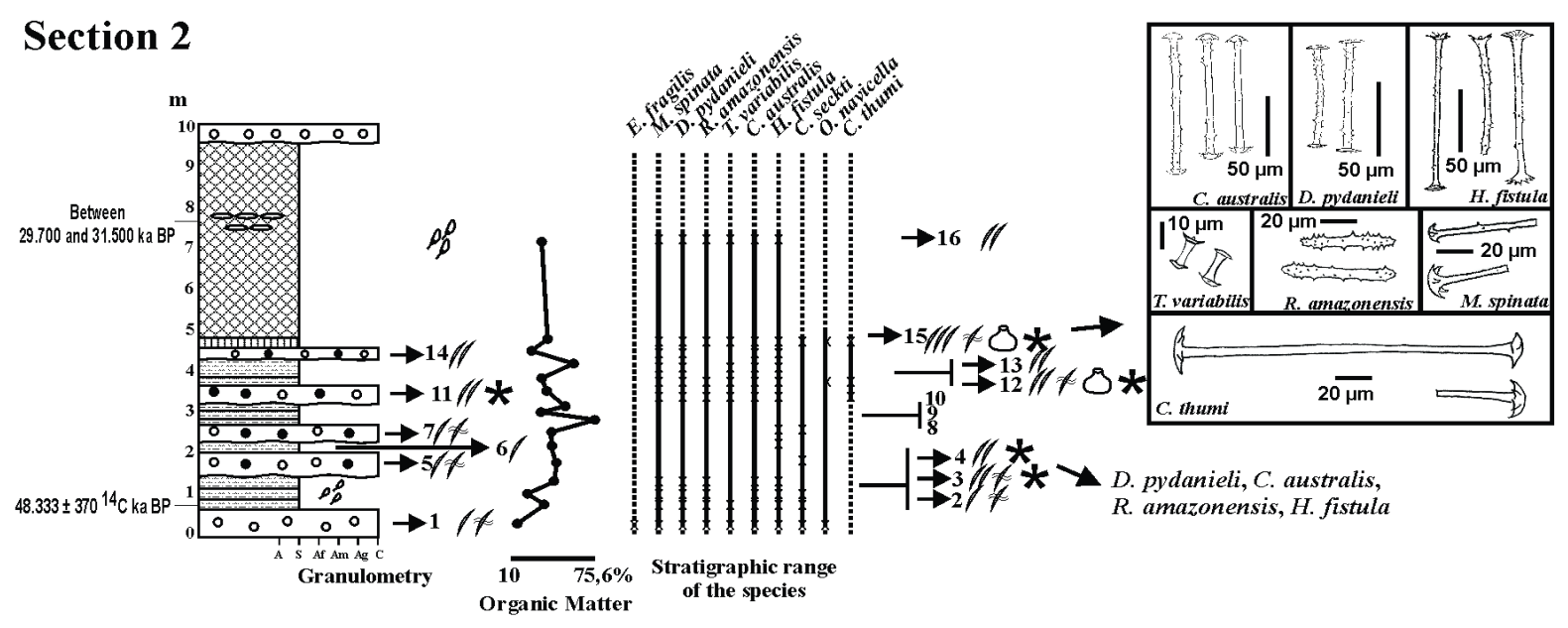

Figure 3. Profile of Section 2 (meters) illustrating from left to right: the results of the textural classification; the percentage of organic matter; the occurrence of the spicules of each sponge species, according to their category and abundance; figures of the gemmoscleres with occurrence in this section. Abbreviations: A, argillite; S, siltstone; Af, fine sandstone; Am, medium sandstone; Ag, coarse sandstone; C, conglomerate/diamictite. Legend as Figure 2. Adaptated from [31] [32].
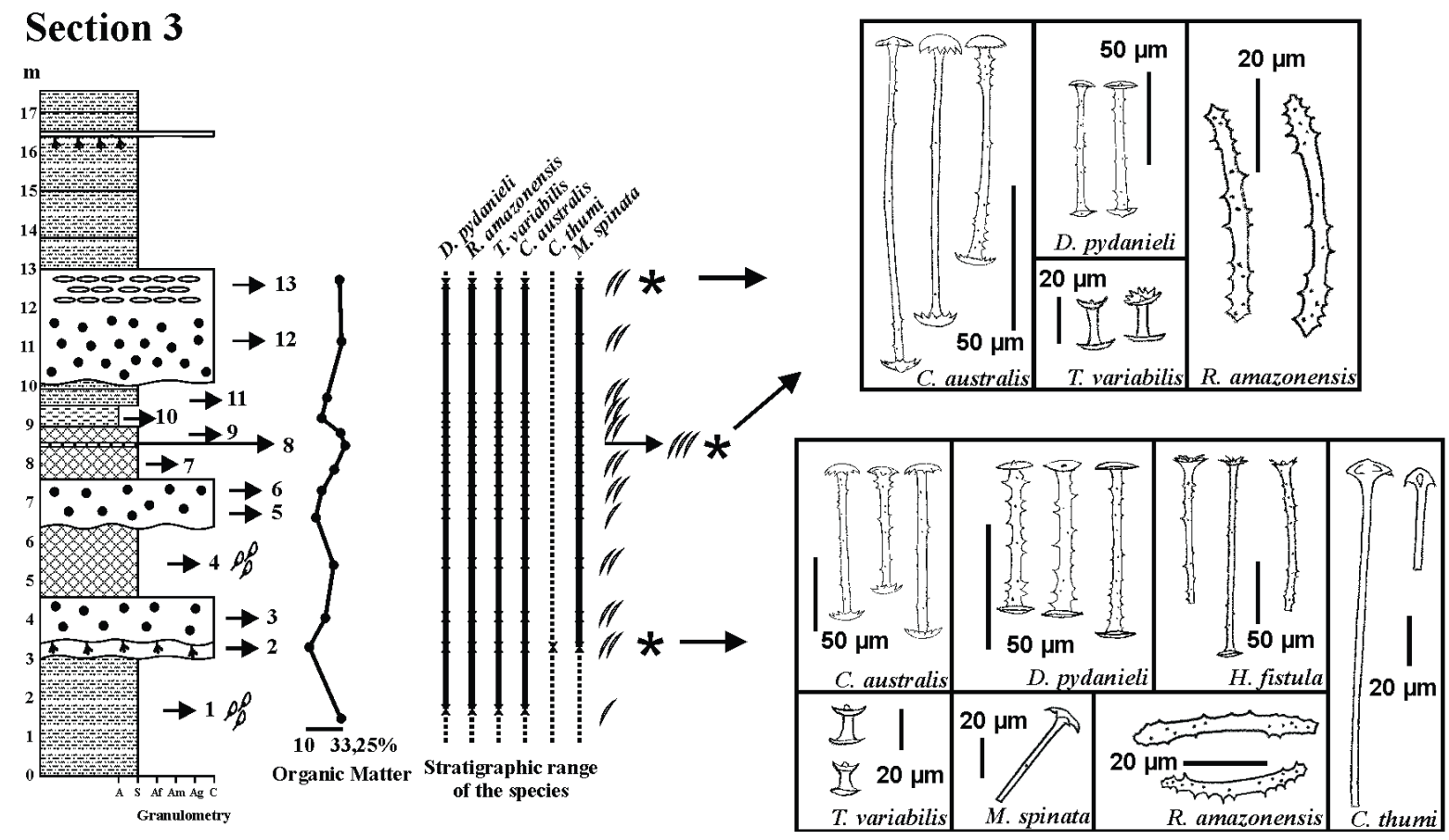

Figure 4. Profile of Section 3 (meters) illustrating from left to right: the results of the textural classification; the percentage of organic matter; the occurrence of the spicules of each sponge species, according to their category and abundance; figures of the gemmoscleres with occurrence in this section. Abbreviations: A, argillite; S, siltstone; Af, fine sandstone; Am, medium sandstone; Ag, coarse sandstone; C, conglomerate/diamictite. Legend as Figure 2. Adaptated from [31] [32].

Section 2 and Layers \# 4, 7 (Figure 6(c), Figure 6(d)), and 9 from Section 3. It should be noted that none of the layers of spongillites presented diatom frustules, whereas there were numerous sponge spicules in the diatomites. The ternary diagram (Figure 5) also showed that the layers of spongillites and diatomites were associated with the fine fraction of the sediments, as illustrated in the profiles in Figures 2-4.

\subsection{Analysis of the Sponge Spicules}

The facies that contained abundant spicules from the skeleton of sponges (megascleres and microscleres) and 

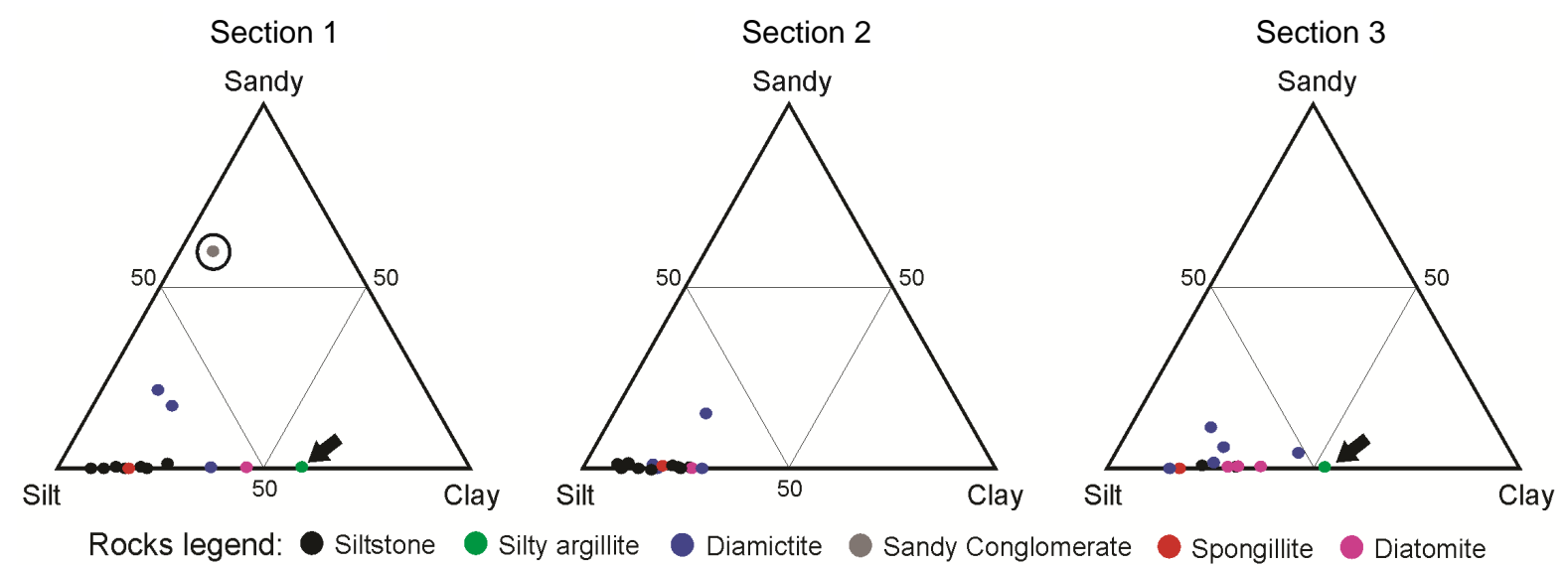

Figure 5. Ternary diagram showing the granulometric relation between sandy/silt/clay in the layers from Sections 1,2 and 3 of the Cemitério Palaeolake. The circle indicates a single layer with higher percentages of sand, Layer \# 2/3 from Section 1. The arrows indicate the layers with higher clay contents, Layer \# 7 from Section 1 and Layer \# 10 from Section 3.

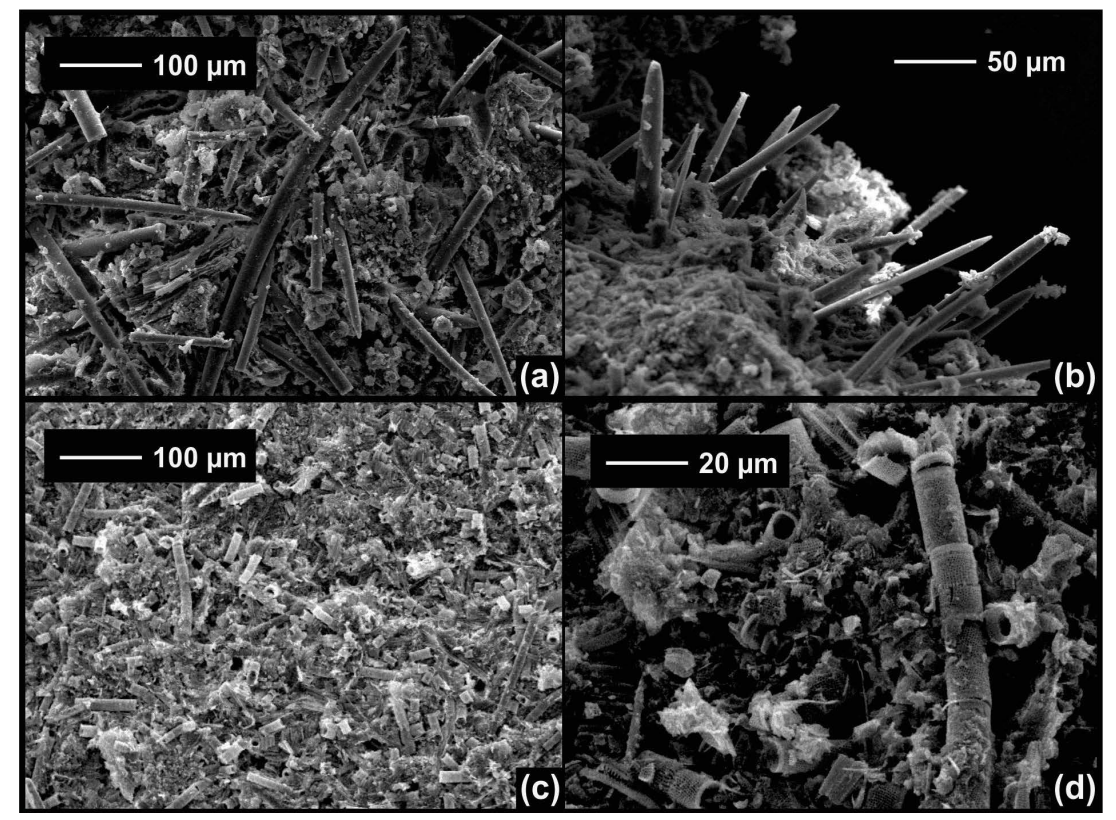

Figure 6. SEM images of the spongillite (a) (b) and diatomite (c) (d), respectively, Layer \# 7 and 8 from Section 3. (a) (b): Sponges megascleres; (c) (d): Diatom frustules.

also from the gemmules (gemmoscleres) consisted of siltstone (Layer \# 11 from Section 1; Layers \# 3, 4 and 12 from Section 2), diamictites (Layer \# 11 from Section 2; Layers \# 2 and 13 from Section 3), and spongillites (Layer \# 15 from Section 2; Layer \# 8 from Section 3). Gemmoscleres of Dosilia pydanieli, Corvoheteromeyenia australis, Radiospongilla amazonensis, and Trochospongilla variabilis occurred in all of these facies (Figures 2-4). However, gemmoscleres of Corvomeyenia thumi and Metania spinata occurred only in the Layers \# 11, 12, and 15 from Section 2 and Layer \# 2 from Section 3 (Figure 3 and Figure 4). It should be noted that M. spinata occurred also with skeletal spicules throughout the three studied profiles from the Cemitério Palaeolake [31], whereas the megascleres of $C$. thumi were restricted to precisely the same layers where its gemmoscleres occurred (Figure 3 and Figure 4). Heterorotula fistula which was only registered in Section 2 [31] occurred also with its megascleres and gemmoscleres (Figure 3).

The facies that contained only abundant spicules from the skeleton of sponges were siltstones (Layers \# 9 and 14 from Section 1; Layer \# 13 from Section 2; Layer \# 11 from Section 3), diamictites (Layer \# 6 from Section 1; Layer \# 14 from Section 2; Layers \# 3, 6 and 12 from Section 3), diatomites (Layer \# 5 from Section 1; Layer 
\#16 from Section 2; Layers \# 4, 7 and 9 from Section 3), and only one of silt-mudstone (Layer \# 10 from Section 3) (Figures 2-4). The spongillites from Layer \# 10 from Section 1 (Figure 2) also showed a predominance of megascleres and microscleres.

\subsection{OM}

The results with respect to the organic content of the different rocks from the Cemitério Palaeolake, in addition to the levels previously characterized by [32] (Layer \# 14 from Section 1 and Layers \# 12 and 15 from Section 2), are presented in Table 1 and illustrated in Figures 2-4. In Section 1, two peaks of OM were recorded, one in Layer \# 4 and another in Layer \# 16. In Section 2, Layers \# 8, 10, and 13 stand out, whereas in Section 3, the highest levels were detected in Layer \# 8. However, when the three profiles from the Cemitério Palaeolake were compared, the boxplot graph (Figure 7) showed that Sections 1 and 2 had the greatest variation in OM, from $7.50 \%$ to $62.10 \%$ and from $10.65 \%$ to $75.60 \%$ (Figure 2 and Figure 3), respectively. The graph also showed that most of the layers from Section 2 had high levels of OM (28\% - 40\%), whereas in Sections 1 and 3, the percentage of OM was less than $30 \%$ in most of the layers (Figure 7).

\subsection{Correlation of the Three Sections from the Paleolake}

On the basis of the sedimentary features and the association of the preserved sponge spicules, it was possible to correlate the three sections from the Cemitério Palaeolake (Figure 8). The deposit thickest sequence was detected in Section 1, where it reached approximately $26.5 \mathrm{~m}$ in height (Figure 2). On the basis of the dating provided by [31] [32], it became clear that the base of this Palaeolake was mainly exposed in Section 1 and consisted of diamictites (Layer \# 1) overlaid by a sandy conglomerate (Layer \# 2/3), with a combined thickness of approximately $6 \mathrm{~m}$ (Figure 2). The basal diamictites in both Sections 1 and 2 were characterized by the presence of clasts of exclusively mineral origin (Table 1). Sponge spicules from five species of both lentic and lotic environments were also observed in both layers (Figure 8).

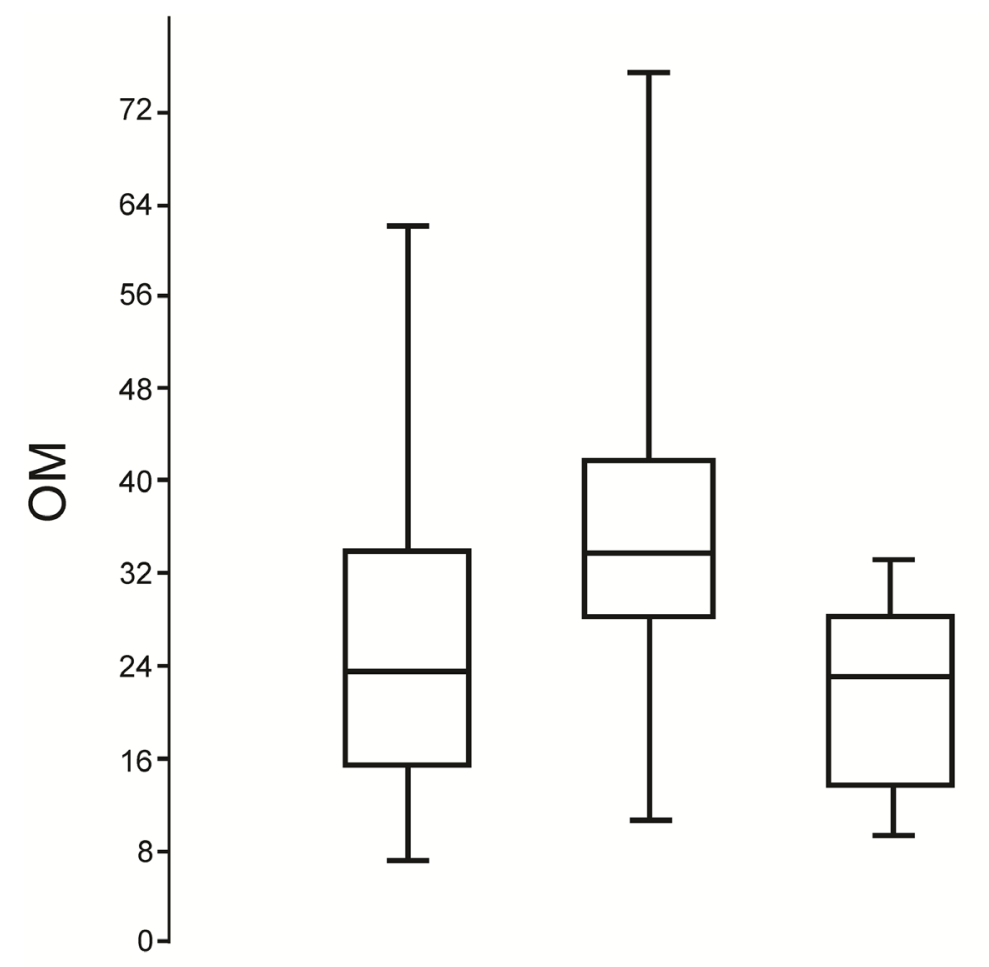

Section 1 Section 2 Section 3

Figure 7. Boxplot Graph showing the variation of organic matter in the Sections 1, 2 and 3 of the Cemitério Palaeolake deposit. 


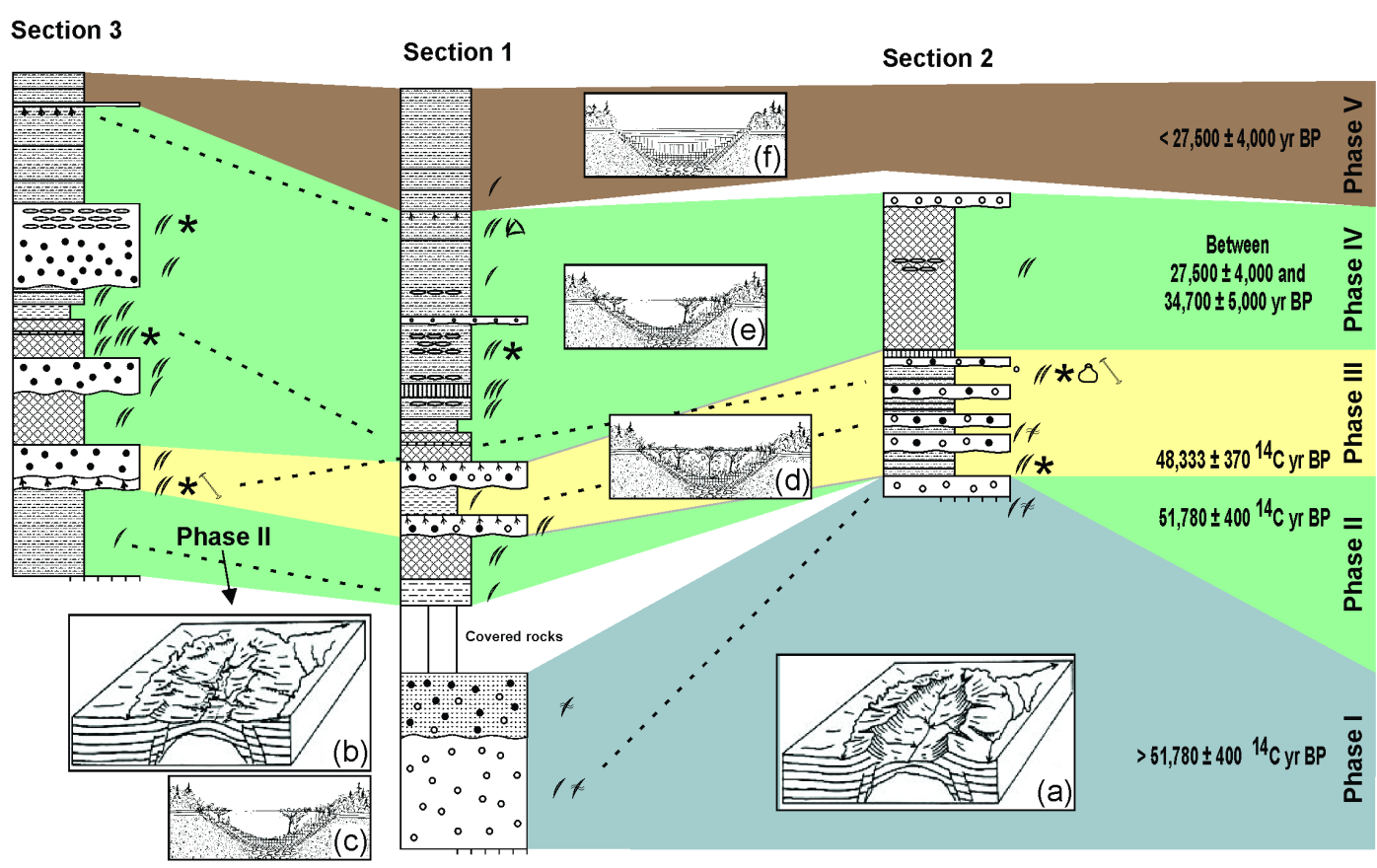

Cold and rainy

Cold and wet Seasonal and gradually warming

Cold and dry

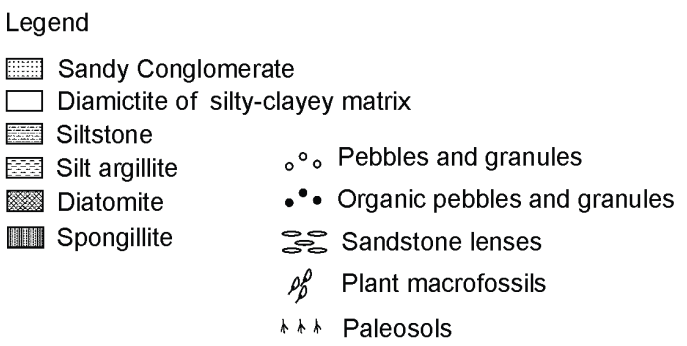

Figure 8. Lithostratigraphic profiles of the Cemitério Palaeolake, Catalão, Goiás, illustrating the correlation among the three analyzed sections (dashed line), the corresponding palaeoclimatic interpretations and geomorphological steps of the dome structure erosion (a-b, after [44]), taking to formation of the basin and its final colmatation (c-f; modified from [45]).

The upper part of the basal portion of Section 1 was lost during the recovery procedures. A layer of siltstone followed, with high levels of OM and presence of sponge spicules exclusively from a lentic environment (Layer \# 4, Figure 2). Similar features occurred in Layer \# 1 from Section 3, allowing these two sections to be correlated (Figure 8).

The subsequent layers in Section 1 corresponded to two diamictites separated by a layer of silt-mudstone (Layers \# 6, 7 and 8; Figure 2). Alternating layers of diamictites and siltstones characterized the longest sequence in Section 2 (Layers 2 - 15; Figure 3). The diamictites in these two sequences, from Sections 1 and 2, presented clasts of both mineral and organic origin (Table 1), allowing for a correlation to be made between these two sections. This correspondence was also confirmed by the considerable decrease in spicules in both sections.

The correlation found between Layers \# 11 to 15 from Section 2 and Layer \# 2 from Section 3 is based on the occurrence of C. thumi, which is restricted to these layers (Figure 8).

Field observations [42] indicated two guide levels between Sections 1 and 3. The first consists of a thin layer of spongillites between two layers of diatomites, occurring in Layers \# 7, 8, and 9 from Section 3 (Figure 2 and Figure 4) and juxtaposed to that of the diamictites in Layer \# 8 from Section 1 (Figure 8). The second corresponds to a paleosols facies sampled at Section 1 (Layer \# 14; Figure 2) and top of Section 3 (Figure 8). 


\section{Discussion}

The ages provided by [31] [32] for Sections 1 and 2 of the Cemitério Palaeolake, together with the sedimentary features and associated spicules, suggest the existence of five distinct phases of climatic regimes that influenced the nature of the deposit from the base to the top (Figure 8).

\subsection{Phases I and II}

Phase I, which was older than 51,780 ${ }^{14} \mathrm{C}$ yr BP [32], was formed during high levels of precipitation, as indicated by the diamictites and also by the conglomerates, favouring flows of unselected sediments resulting from the erosion of the dome and that accumulated in the areas with less steep slopes (Figure 8(a)). Machado and colleagues [34] demonstrated that a similar process is occurring in the dome of the Serra Negra, which exhibits a centripetal drainage system that accumulates in the centre. Phase I can be taken as the intermediate step of erosion of dome structures as described by [44]. The incorporation of organic clasts during this phase (Figure 2 and Figure 8) indicates a change from an arid to a humid climate. Thus, the occurrence of higher pluviosity favoured the formation of a lotic system, forming a layer of sandy conglomerate, which retained sponge spicules from lotic environments.

Phase II, which was dated from 51,780 $\pm 400{ }^{14} \mathrm{C}$ yr BP [32], features a shallow lake system with free permanent water coverage, intense illumination in the water column, scattered macrophytes, and stable water levels (Figure 8(b), Figure 8(c)), as indicated by the diatomite layer containing the skeletal spicules of sponges from lacustrine environments [31]. Machado and colleagues [34] demonstrated the presence of abundant megascleres and microscleres in the bottom sediments of the actual lake on the Serra Negra Dome and attributed this to the perennial nature of this lake. Volkmer-Ribeiro and colleagues [26] reported that the predominant species of sponges in the diatomite rocks in the northeast region of Brazil are those that occur in shallow lakes exposed to full sunlight and limited water movement.

Corvoheteromeyenia australis, for the first time identified in a spongillite-forming community, is endemic to South America and was described from living material collected in Argentina [46] [47]. Its occurrence in the Cemitério Palaeolake, from Phase I, and its absence in the current Serra Negra Lake [34], indicates that a colder climate prevailed in central Brazil during the formation of the Cemitério Palaeolake.

Table 2 provides a comparison of palaeoclimatic interpretations of the developmental stages of the Palaeolake

Table 2. Interpretations of the climatic evolution along the 5th phases detected in the Cemitério Palaeolake, compared with those already presented for central/southeast Brazil.

\begin{tabular}{|c|c|c|c|c|}
\hline Age & $\mathrm{F}$ & Facies & Interpretation & Bibliographic comparison \\
\hline $\begin{array}{l}>51,780 \pm 400 \\
{ }^{14} \mathrm{C} \text { yr BP. }\end{array}$ & I & $\begin{array}{l}\text { Layers \# } 1 \text { and } 2 / 3 \\
\text { from Section } 1 \text {; Layer } \\
\# 1 \text { from Section } 2\end{array}$ & Cold and rainy & $\begin{array}{l}\text { A cold and dry climate between } 40,000 \text { and 50,000 yr } \\
\text { BP in Salitre [2]. }\end{array}$ \\
\hline $\begin{array}{l}51,780 \pm 400 \\
{ }^{14} \mathrm{C} \text { yr BP. }\end{array}$ & II & $\begin{array}{l}\text { Layers \# } 4 \text { and } 5 \\
\text { from Section } 1 \text {; } \\
\text { Layer \# } 1 \text { from } \\
\text { Section } 3\end{array}$ & Cold and wet & $\begin{array}{l}\text { An increase in moisture at low temperatures as from } \\
45,000 \text { yr BP in Salitre and Serra Negra [1] [2]. }\end{array}$ \\
\hline $\begin{array}{l}\text { Between } \\
34,700 \pm 5000 \\
\text { and } 48,333 \pm 370 \\
{ }^{14} \mathrm{C} \text { yr BP. }\end{array}$ & III & $\begin{array}{l}\text { Layers \# 6, } 7 \text { and } 8 \\
\text { from Section 1; } \\
\text { Layers \# } 2 \text { - } 15 \\
\text { from Section } 2 \text {; } \\
\text { Layers \# } 2 \text { and } 3 \\
\text { from Section } 3\end{array}$ & $\begin{array}{l}\text { Seasonal and } \\
\text { gradually warming }\end{array}$ & $\begin{array}{l}\text { A slow decrease in vegetation as from } 36,700 \text { yr BP in } \\
\text { São Paulo [8]; Seasonality during this period in Serra Negra } \\
\text { [1]; Stable water levels in the Salitre basin between 33,000 } \\
\text { and } 40,000 \text { yr BP [2]. However, both records [1] [2] } \\
\text { reported an increase in temperature during this period. } \\
\text { A more seasonal climate is suggested from } 28.300 \text { to } \\
32,000 \text { yr BP in Cromínia [3] [4]. }\end{array}$ \\
\hline $\begin{array}{l}\text { Between } \\
27,500 \pm 4000 \\
\text { and } 34,700 \pm 5000 \\
\text { yr BP. }\end{array}$ & IV & $\begin{array}{l}\text { Layers \# 9-14 } \\
\text { from Section 1; } \\
\text { Layers \# } 16 \text { from } \\
\text { Section 2; Layers \# } \\
4 \text { - } 13 \text { from Section } 3\end{array}$ & Cold and wet & $\begin{array}{l}\text { Expansion of the Atlantic forest and high humidity in } \\
\text { the period between 28,225 and 30,400 yr BP, in the region } \\
\text { of São Paulo [8]; Presence for the Cromínia deposit of a } \\
\text { shallow lake surrounded by open countryside with a wetter } \\
\text { and probably cooler period between } 20,000 \text { and } 27,000 \mathrm{yr} \\
\text { BP, when compared to the present [3] [4]; The same was } \\
\text { indicated for Águas Emendadas between } 21,000 \text { and } \\
24,000 \mathrm{yr} \text { BP [6]. Higher rainfall in a slightly cooler and } \\
\text { less seasonal climate between } 26,206 \text { and } 28,166 \mathrm{yr} \mathrm{BP} \text { [27]. }\end{array}$ \\
\hline $\begin{array}{l}<27,500 \pm 4000 \\
\text { yr BP. }\end{array}$ & $\mathrm{V}$ & $\begin{array}{l}\text { Layers \# } 15-18 \\
\text { from Section } 1\end{array}$ & Cold and dry & $\begin{array}{l}\text { Colder and drier conditions in southern and southeastern } \\
\text { Brazil during the Last Glacial Maximum (LGM), as from } \\
\text { 25,000 yr BP [2] [5]. }\end{array}$ \\
\hline
\end{tabular}


with other records produced for central Brazil. The oldest dating available for this region was presented by [2], through the analysis of pollen and algae deposited in the Serra do Salitre, MG, alkaline carbonatite dome, which is similar to those of the Cemitério Palaeolake and the Serra Negra Lake (Figure 1). The authors based their arguments on a correlation with a deposit studied precisely in the Serra Negra Lake [1], and with the oldest dating of 42,000 yr BP, and indicated a cold and dry climate between 40,000 and 50,000 yr BP. In both the Salitre and Serra Negra deposits, that phase was followed by a change in the landscape as from 45,000 yr BP. The increase in tree pollen, with the occurrence of some originating from colder climates, suggests an increase in moisture at low temperatures. The proposed sequence for Phases I and II of the Cemitério Palaeolake does not differ from the palaeo-interpretation, although the results presented for Phase I suggest that an increase in rainfall and humidity began at a time earlier than $51,780{ }^{14} \mathrm{C}$ yr BP. A record submitted by [8] obtained from the coastal mountains, in this case in São Paulo, showed that the Atlantic Forest expanded in the same region during the last $100,000 \mathrm{yr} \mathrm{BP}$, thus confirming the occurrence of wetter periods during the late Pleistocene, as was also indicated in the deposits from central Brazil.

To explain the colder temperature during the late Pleistocene, several authors have suggested that polar incursions from the south might have been more frequent during that period [2] [5] [7] [8]. Furthermore, Ledru and colleagues [8] also suggested that these incursions had a significant impact on the climate of South America during the last glacial period. This would explain the presence of $C$. australis in the Cemitério Palaeolake as well as its bio-geographical position today, with its occurrence restricted to southern South America.

\subsection{Phase III}

Phase III, dated from just under $34,700 \pm 5000$ to $48,333 \pm 370{ }^{14} \mathrm{C}$ yr BP [31] [32], is characterized by an alternating sequence of siltstones and diamictites, as seen mainly in Section 2, Layers \# 2 to 15, where there was still a layer of spongillite in the top layer (Figure 3 and Figure 8). This alternation indicates the presence of periods of heavy rainfall that caused mudslides (diamictites), intercalated with long periods of lacustrine sedimentation (siltstones and spongillite). In fact, Machado and colleagues [31] indicated the rare occurrence of sponge spicules typical of lotic environments, whereas spicules from sponges typical of lakes were abundant (Figure 3). However, the layers of siltstone in Section 2 were distinguished from the other facies in the Cemitério Palaeolake deposit by the high levels of OM (Figure 7) as well as by the abundance of spicules, there included gemmoscleres (Figure 3).

Gemmules are asexual reproductive structures produced by particularly continental sponges, during periods of adversity such as dry periods [48] [49]. However, the specific identification of the gemmoscleres from the Cemitério Palaeolake revealed that Layers \# 11, 12, and 15 from Section 2 and Layer \# 2 from Section 3, on top of Phase III, were unique in showing that the entire sponge community of the Palaeolake, including the species $C$. thumi, was in the process of forming gemmules (Figure 3 and Figure 4). The latter species only occurred during periods of drastic reduction in the water column and encrusted substrates very near the water surface, as was seasonally observed by [50] in the seasonal lakes of the Maracá Island that, with the exception of $H$. fistula, contained the same community of sponges detected in Phase III. Volkmer-Ribeiro and Turcq [38] report this species as an excellent palaeoenvironmental indicator. Moreover, several studies of columns of sediment from the Serra dos Carajás, Pará, have used the presence of $C$. thumi gemmoscleres to define successive stages of drought during the Holocene [16] [17] [51] [52]. Machado and colleagues [32] detected fully preserved gemmules of C. thumi precisely in Layers \# 12 and 15 from Section 2, thus corroborating with the proposed interpretation. Furthermore, C. thumi also indicates an increase in temperature during the development of Phase III, with warmer dry seasons, at least when compared with the other phases of the Cemitério Palaeolake. Interestingly, Heterorotula fistula was restricted to Section 2 [31] and was the most abundant species among diatomites from the northeast of Brazil [26].

This fluctuation in water level during Phase III of the Cemitério Palaeolake explains the higher organic levels, between $28 \%$ and $40 \%$, in the layers of Section 2 (Figure 7). These levels were similar to those detected in the sediments from the current Serra Negra Lake, with just over 30\% OM [34]. However, an abundance of spicules from the skeletal structure of the sponges, which are suggestive of continuous sponge production allowed by permanent water levels as indicated for the Serra Negra Lake, only occurred in a thin layer of siltstone at the top of Phase III (Layer \# 13; Figure 3), and so, for a very short period of time. The high altitudes common to Cemitério Palaeolake and Serra Negra Lake indicate that the peaty sediments in Phase III of the palaeolake (Figure 
8(d)) were produced during a similar microclime, although more seasonal than the actual one acting on Serra Negra Lake.

The palaeoenvironmental and palaeoclimatic interpretations presented for Phase III of the Cemitério Palaeolake can be compared with those proposed by [8] (Table 2), who suggested that a slow decrease in vegetation occurred from 36,700 yr BP. This period could be correlated with the sequence of Phases II and III of the Cemitério Palaeolake. In this sense, the retraction of the forest could have been caused by the occurrence of successive periods of drought. De Oliveira [1] also inferred the occurrence of seasonality in the Serra Negra deposit during this period. In contrast, Ledru and colleagues [2] reported more stable water levels in the Salitre basin between 33,000 and 40,000 yr BP and suggested the higher altitude of Salitre in relation to Serra Negra might account for this difference. However, these authors cited a gap in the Salitre record, followed by the formation of a peat bog, just over 32,000 yr BP. Both records [1] [2] reported an increase in temperature, as proposed in the present study for Phase III of the Palaeolake. Likewise, a more seasonal climate, similar to the current one, was suggested by [3] [4] in profiles collected from a vereda (Buritizal) at a height of $710 \mathrm{~m}$ in the region of Cromínia, Goiás. These authors emphasized that prior to 32,400 yr BP, a vereda and a gallery forest existed on the site and the surrounding area was occupied by a wooded Cerrado. Barberi and colleagues [6], who analysed pollen obtained from a vereda on the top of a plateau $(1040 \mathrm{~m})$ in Águas Emendadas, near the city of Brasilia, suggested that peat deposition began in the area 30,480 yr BP (Table 2).

\subsection{Phase IV}

Phase IV, which has been dated to be between 27,500 \pm 4000 and 34,700 \pm 5000 yr BP [31], includes the longest sequences in Sections 1 (Layers \# 9 to 14, Figure 2) and 3 (Layers \# 4 to 13; Figure 4), and the diatomite from Section 2 (Layer \# 16; Figure 3) (Figure 8). Diatomites and siltstones with abundant spicules from the skeletal structure of the sponges are typical facies in this phase and indicate a basin covered with free permanent water, intense illumination in the water column, and scattered macrophytes (Figure 8(e)), as was also described in Phase II. Fluctuations in the water column which also occurred during this phase are documented in the spongillite as well as in the layers with abundant spicules and gemmoscleres. However, these periods could not be compared to those described for Phase III. The absence of $C$. thumi and, moreover, of gemmoscleres from $M$. spinata indicate that the reductions were minimal and short, indicating the predominance of a wetter and less seasonal climate. The formation of diamictites in Section 3 is noteworthy, as observed during this phase (Figure 4 and Figure 8). However, these are distinct from the other diamictites formed in the Palaeolake because the clasts exclusively consisted of OM [42]. Accordingly, this observation confirmed the presence of lighter rainfall during this period, thus favouring the leaching of the lighter, organic, clasts into the basin.

Concurrent with Phase IV of the Cemitério Palaeolake (Table 2), [1] [2] signalled a hiatus in the Salitre and Serra Negra deposits that was probably due to local events, since the result for this phase of the Cemitério Palaeolake indicated the existence of a period with permanent water levels and, therefore, wetter conditions. Such results conform also those of [8], who recorded the expansion of the Atlantic forest and high humidity during the period between 28,225 and 30,400 yr BP, in the region of São Paulo. Moreover, the records submitted for the Cromínia deposit [3] [4] indicated a retraction of arboreal and shrub elements in the region from 28,300 to 32,000 yr BP, followed by substitution of the vereda by a shallow lake surrounded by open countryside. This suggests a wetter and probably cooler period between 20,000 and 27,000 yr BP, compared to the present. For the profile studied in the vereda peat bog in Águas Emendadas [6] between 24,000 and 25,790 yr BP, pollen grains and algal remains indicate the presence of a marsh surrounded by patches of open Cerrado and gallery forest on top of the plateau. In addition, between 21,000 and 24,000 yr BP, the vegetation was denser than that of the present period, with abundant aquatic plants and some trees from cooler climates, suggesting a wetter and probably cooler climate. In more lowland terrains in central Brazil, Almeida and colleagues [27] presented the results of palaeoenvironmental interpretations in spongillite deposits from the region of João Pinheiro, MG (average altitude of 560 to $600 \mathrm{~m}$ ). According to the composition of the identified spicules and sponge community, the authors described the development of these palaeo-basins to be from 28,166 yr BP. At an earlier period, they suggested the basin was formed over a slight depression in the terrain, giving rise to a shallow lake and initially favouring diatoms. This phase was followed by a period that was more favourable to sponge settlement, mainly by M. spinata, without the formation of gemmules, which led the authors to suggest that concurrent with the deepening of the pond, there was a higher rainfall in a slightly cooler and less seasonal climate. Later, for the period 
between 26,206 and 26,656 yr BP, due to the presence of gemmoscleres, the authors reported a reduction in the water level and suggested periods of intermittent short droughts and rainy seasons, although without heavy downpours. Thus, these results also corroborate those presented for Phase IV of the Cemitério Palaeolake. Almeida and colleagues [27] reported an age between 13,887 and 14,495 yr BP for the layers of "pure" spongillite deposits from João Pinheiro, thus impeding any correlation with spongillite deposits from the Cemitério Palaeolake.

\subsection{Phase V}

Phase V covered the period of less than $27,500 \pm 4000$ yr BP [31] and is characterized by siltstone facies sampled only at the top of Section 1, Layers \# 15 to 18 (Figure 2 and Figure 8). The volume of OM increased, whereas sponge spicules decreased until they completely disappeared. This phase witnessed the complete filling of the basin (Figure 8(f)) and can be correlated with the Last Glacial Maximum (LGM), which occurred between 11,000 and 25,000 yr BP, as indicated by [2] [5], where colder and drier conditions prevailed in southern and central Brazil (Table 2).

\section{Genesis of Bio-Siliceous Accumulations}

The layers of spongillites in southeastern Brazil [19] [26] [27] were thick and, at the base, contained spicules of $M$. spinata, with contributions from $D$. pydanieli and $H$. fistula and, above, in the transition to the layer of peat, $T$. variabilis and $R$. amazonensis. In the top, peaty layer, there were also spicules from $C$. thumi and gemmoscleres from all six species. The layers of spongillites in the Cemitério Palaeolake deposit were thin and contained C. australis [31], whereas C. thumi and $H$. fistula only occurred in the spongillites in Layer \# 15 from Section 2 (Figure 3), which also contain an exceptional amount of whole gemmules [32]. Volkmer-Ribeiro and Motta [19] attributed the existence of the most basal layer of the spongillite deposits to a deeper palaeo-environment with a greater abundance of submerged macrophytes, the preferred substrate of $M$. spinata [33], which did not occur during the evolution of the Cemitério Palaeolake. The absence of diatoms in the spongillite layers, as also observed in the Cemitério Palaeolake, is a typical feature of such deposits, precisely because the abundance of macrophytes prevents light, which is essential for photosynthetic organisms such as diatoms, from penetrating the body of water. However, the presence of sponge spicules is common in layers of diatomites [9] [13] [23] [26]. Thus, the alternating layers of diatomites and spongillites in the Cemitério Palaeolake deposit indicates variations in the permanence of water levels, causing the establishment of a greater or lesser degree of macrophytic vegetation and, concomitantly, more or less light penetration.

The decrease in the availability of water from Phase I to Phase II, which favoured diatoms imparted a significant effect on the characteristics of the lentic environment inside the Catalão I dome. This interpretation has previously been inferred for shallow basins, remarkable for the accumulation of diatoms in northeastern Brazil [26]Moreover, Moyle and Dolley [22] reported that the areas of diatomites in continental U.S.A. were also associated with small lake systems formed by the clogging of lotic systems. Almeida and colleagues [27], when comparing sponge species present in two profiles of lakes with spongillite deposits in the region of João Pinheiro, MG, confirmed the results reported by [26] and added that, in the case of karst environments, the process of forming palaeolakes that favour the production of diatoms occurred due to the slow dissolution of carbonate rock, without the immediate establishment of macrophytes, but instead a shallow sheet of water exposed to the sun. In the case of spongillites, the karst process would involve the undermining of the bottom of lakes, thus generating initially deeper basins. There is no doubt that the intense lotic environments during Phase I (Figure 8(a)), contributed to the large volume of water and, consequently, to the increased physical and chemical weathering at the bottom of the lake, which is typical of karstic lakes, as also noted by [31].

The availability of silica is important in the formation of sponge spicules [53], as well as that of diatomic algae [22]. Machado and colleagues [34] highlighted the high levels of silica dissolved in the water of the Serra Negra Lake (8 to $32 \mathrm{mg} / \mathrm{L}$ ) and showed that these were derived from the rocks in the volcanic dome. Pisera and Sáez [23], who described Ephydatia chileana from gemmules fully preserved in the diatomite layer within alluvial-lacustrine deposits from the Late Miocene Quillagua Formation, in the Atacama region of Chile, attributed the high silica content in the lake environment to the volcanic origin of the sediments, thus encouraging the development of diatoms and freshwater sponges. Moreover, Moyle and Dolley [22] indicated that diatomite deposits in North American were generally associated with volcanic terrains, which supplied the silica needed for the 
skeletal development of diatoms. Barbosa and colleagues [37] reported that the Igneous Province of Upper Paranaíba are rich in silicate rocks. Given that the pyroclastic deposits and lavas of this Province also covered large areas of the Mata Corda Group [36] [54], it was reasonable for us to infer that these rocks were, and still are, an important source of silica for the surrounding aquatic environments, as are those of the Areado Group, as indicated by [55]. The rocks of the Igneous Province of the Alto Paranaiba are located between the Paraná and São Francisco Basins, one of the most important watersheds in Brazil (Figure 1).

Hilgen and Krijgsman [30], who studied the Tripoli diatomite formation in three distinct deposits in Sicily, Italy, astronomically dated at $7005 \mathrm{Ma}$, highlighted the intercalated occurrence of homogeneous marls/clays, diatomites, and layers of sapropels, and noted a very strong relationship between the sapropels and diatomites, relating the availability of nutrients in the sapropel as being of paramount importance for the intense production of diatomic algae and thus formation of diatomites. Accordingly, the reduction in the water column during the formation of the spongillites in the Cemitério Palaeolake favoured the accumulation of OM and nutrient supply for consumption by the diatoms, as new rainfall occurred. Moyle and Dolley [22] stated that nutrients such as phosphates and nitrates were made available in the water column when organisms died and decomposed on the lake bottom. This would explain the presence of diatomites and spongillites in the Cemitério Palaeolake, and their intercalation, as in the case of Layers \# 7, 8, and 9 from Section 3 or even the sequence of spongillites followed by diatomites in Section 2 (Layers \# 15 and 16) (Figure 3 and Figure 4).

Regarding the need of diatoms for light, the formation of diatomites was linked to the wetter phases of the Cemitério Palaeolake (Phases II and IV), which suggested greater cloud cover and less sun exposure. However, photosynthetic organisms such as diatom algae would not have produced such deposits without full light hitting the water column of the Palaeolake. In this regard, Hilgen and Krijgsman [30] highlighted a very clear correlation between the depositional periods of sapropels and diatomites with the patterns of maximum insolation and minimum precession, particularly in the Northern Hemisphere. The formation sequence of the two diatomite facies dated in the Cemitério Palaeolake (Phase II and IV, Figure 8), corresponded to a periodicity of approximately 22,000 yr, which coincided with the complete precession cycle of approximately 20,000 yr prior [56]. Berger and Loutre [56] produced figures for the astronomical parameters of the Earth's orbit, eccentricity, obliquity, and precession in the Quaternary. In terms of the precession cycle, the illustrations provided by the authors showed maximum values shortly before 50,000 yr BP. Around 30,000 yr BP, the precession values were increasing and reached their maximum just before 20,000 yr BP. Thus, in the case of frequent clouds and shorter sun exposure, the occurrence of an orbital event that increased solar intensity in the Southern Hemisphere such as during maximum precession, could have favoured the formation of the diatomites during Phases II an IV in the Cemitério Palaeolake.

\section{Final Remarks}

The results of the analysis of the freshwater sponge spicules from the Cemitério Palaeolake deposit were highly significant towards not only the reconstitution of palaeoenvironments, but particularly those of palaeoclimates. At least two species could be here highlighted as good climatic indicators. Corvoheteromeyenia australis, which is now restricted to southern South America, stands out as an indicator of colder and wetter weather. Accordingly, the data suggest that polar incursions originating in Antarctica were common during the late Pleistocene and may have played a notable role in the humidity of central Brazil during the period $>51,780 \pm 400{ }^{14} \mathrm{C}$ yr BP until the beginning of the LGM, when drier conditions began to predominate. Corvomeyenia thumi is again confirmed as a sponge species indicator of environments subjected to marked seasonal droughts. In the case of the Cemitério Palaeolake, the restriction of the presence of this species a little before 34,700 $\pm 5000 \mathrm{yr} \mathrm{BP}$, at the upper part of Phase III, suggests the occurrence of a more seasonal climate.

The Cemitério Palaeolake stands out as a remarkable deposit, if not unique one in Brazil and in the world, to illustrate the formation of spongillites and diatomites in a same basin. The present study disclosed also environmental conditions, at Phase II and IV, which were more favourable for diatoms as demonstrated by their more voluminous facies. In spite of the fact that the spongillites of the Palaeolake were distinct from other spongillite deposits in the country, the Cemitério Palaeolake was also seen to favour the establishment of communities of sponges common to the Cerrado Biome. In this sense, the karst processes that led to the formation of small palaeo-basins in central Brazil during the Quaternary, and that are still operating, as in the current Serra Negra Lake, enabled/enable the formation of lakes under environmental conditions that have favoured the continued 
existence of a unique sponge community from at least $51,780 \pm 400{ }^{14} \mathrm{C}$ yr BP.

\section{Acknowledgements}

V. S. Machado acknowledges the Brazilian Research Council "Conselho Nacional de Desenvolvimento Científico e Tecnológico" (CNPq) for the Ph.D. fellowship. C. Volkmer-Ribeiro acknowledges CNPq for granting of the Universal Project (Process 481555/2009-9). R. Iannuzzi acknowledges CNPq for research fellowship granted (Process PQ305687/2010-7 and PQ309211/2013-1). The authors are indebted to an anonymous referee for the critical comments on the manuscript.

\section{References}

[1] De Oliveira, P.E. (1992) A Palynological Record of Late Quaternary Vegetational and Climatic Change in Southeastern Brazil. Ph.D. Dissertation Thesis, Ohio State University, Columbus.

[2] Ledru, M.P., Braga, P.I.S., Soubiès, F., Fournier, M., Martin, L., Suguio, K. and Turcq, B. (1996) The Last 50,000 Years in the Neotropics (Southern Brazil): Evolution of Vegetation and Climate. Paleogeography, Paleoclimatology, Paleoecology, 123, 239-257. http://dx.doi.org/10.1016/0031-0182(96)00105-8

[3] Ferraz-Vicentini, K.R. and Salgado-Labouriau, M.L. (1996) Palynological Analysis of a Palm Swamp in Central Brazil. Journal of South American Earth Science, 9, 209-219. http://dx.doi.org/10.1016/0895-9811(96)00007-7

[4] Salgado-Labouriau, M.L., Casseti, V., Ferraz-Vicentini, K.R., Martin, L., Soubiès, F., Suguio, K. and Turcq, B. (1997) Late Quaternary Vegetational and Climatic Changes in Cerrado and Palm Swamp from Central Brazil. Paleogeography, Paleoclimatology, Paleoecology, 128, 215-226. http://dx.doi.org/10.1016/S0031-0182(96)00018-1

[5] Behling, H. and Lichte, M. (1997) Evidence of Dry and Cold Climatic Conditions at Glacial Times in Tropical Southeastern Brazil. Quaternary Research, 48, 348-358. http://dx.doi.org/10.1006/qres.1997.1932

[6] Barberi, M., Salgado-Labouriau, M.L. and Suguio, K. (2000) Paleovegetation and Paleoclimate of "Vereda de Águas Emendadas”, Central Brazil. Journal of South American Earth Sciences, 13, 241-254. http://dx.doi.org/10.1016/S0895-9811(00)00022-5

[7] Behling, H. (2002) South and Southeast Brazilian Grasslands during Late Quaternary Times: A Synthesis. Paleogeography, Paleoclimatology, Paleoecology, 177, 19-27. http://dx.doi.org/10.1016/S0031-0182(01)00349-2

[8] Ledru, M.P., Rousseau, D.D., Cruz Jr., F.W., Riccomin, C., Karmann, I. and Martin, L. (2005) Paleoclimate Changes during the Last 100,000 yr from a Record in the Brazilian Atlantic Rainforest Region and Interhemispheric Comparison. Quaternary Research, 64, 444-450. http://dx.doi.org/10.1016/j.yqres.2005.08.006

[9] Moura, A. (1958) Espongilídeos fósseis no diatomito de Azenhas do Vale de Atela (Alpiarça). Memórias e Notícias, 46, 23-33.

[10] Racek, A.A. (1974) The Waters of Merom: A Study of Lake Huley. IV. Spicular Remains of Fresh-Water Sponges (Porifera). Archiv für Hydrobiologie, 74, 137-158.

[11] Harrison, F.W., Gleason, P.J. and Stone, P.A. (1979) Paleolimnology of Lake Okeechobee, Florida: An Analysis Utilizing Spicular Components of Freshwater Sponges (Porifera: Spongillidae). Notulae Naturae, 454, 1-6.

[12] Harrison, F.W. and Warner, B.G. (1986) Fossil Freshwater Sponges (Porifera: Spongillidae) from Western Canada: An Overlooked Group of Quaternary Paleoecological Indicators. Transactions of the American Microscopical Society, 105, 110-120.

[13] Stubblefield, A. (2012) The early Pliocene (Blancan) Fish Fry Layer, Always Welcome Inn, Baker City, Northeast Oregon. Eastern Oregon Geology Journal, 9. http://www.eou.edu/geology/eastern-oregon-geology/

[14] Cordeiro, R.C., Turcq, B., Suguio, K., Volkmer-Ribeiro, C., Silva, A.O., Sifeddine, A. and Martin, L. (1997) Holocene Environmental Changes in Carajás Region (Pará, Brazil) Recorded by Lacustrine Deposits. Verh International Verein Limnology, 26, 814-817.

[15] Turcq, B., Sifeddine, A., Martin, L., Absy, M.L., Soubiès, F., Suguio, K. and Volkmer-Ribeiro, C. (1998) Amazon Forest Fires: A Lacustrine Report of 7,000 Years. Ambio, 27, 139-142.

[16] Sifeddine, A., Martin, L., Turq, B., Volkmer-Ribeiro, C., Soubiès, F., Cordeiro, R.C. and Suguio, K. (2001) Variations of the Amazonian Rainforest Environment: A Sedimentological Record Covering 30,000 Years. Paleogeography, Paleoclimatology, Paleoecology, 168, 221-235. http://dx.doi.org/10.1016/S0031-0182(00)00256-X

[17] Volkmer-Ribeiro, C., Ezcurra de Drago, I. and Parolin, M. (2007) Spicules of the freshwater Sponge Ephydatia facunda Indicate Lagoonal Paleoenvironment at the Pampas of Buenos Aires Province, Argentina. Journal of Coastal Research, 50, 449-452.

[18] Parolin, M., Volkmer-Ribeiro, C. and Stevaux, J.C. (2008) Use of Spongofacies as a Proxy for River-Lake Paleohydro- 
logy in Quaternary Deposits of Central-Western Brazil. Revista Brasileira de Paleontologia, 11, 187-198. http://dx.doi.org/10.4072/rbp.2008.3.05

[19] Volkmer-Ribeiro, C. and Motta, J.F.M. (1995) Esponjas formadoras de espongilitos em lagoas no Triângulo Mineiro e adjacências, com indicação de preservação de habitat. Biociências, 3, 145-169.

[20] Moreira, I.M.V. (1975) Contribuição ao estudo das Bacillariophyceae (diatomáceas) em diatomitos brasileiros. Acta Biológica Paranaense, 4, 135-198.

[21] Harwood, D.M. (2010) Diatomite. In: Smol, J.P. and Stoermer, E.F., Eds., The Diatoms: Applications for the Environmental and Earth Sciences, Vol. 2, Cambridge University Press, New York, 570-573.

[22] Moyle, P.R. and Dolley, T.P. (2003) With or Without Salt-A Comparison of Marine and Continental-Lacustrine Diatomite Deposits. In: Bliss, J.D., Moyle, P.R. and Long, K.R., Eds., Contributions to Industrial-Minerals Research, U.S. Department of the Interior, U.S. Geological Survey, 1-8.

[23] Pisera, A. and Sáez, A. (2003) Paleoenvironmental Significance of a New Species of Freshwater Sponge from the Late Miocene Quillagua Formation (N Chile). Journal of South American Earth Sciences, 15, 847-852. http://dx.doi.org/10.1016/S0895-9811(03)00012-9

[24] Motta, J.F.M., Cabral, JR.M. and Campanha, V.A. (1986) Diatomitos e espongilitos no Estado de São Paulo. Anais Congresso Brasileiro de Geologia, Giânia, 34, 2329-2341.

[25] Souza, D.D.D., Jordão, M.A.P., Dias, E.G.C.S. and Neves, M.R. (1988) Estudos preliminares de beneficiamento de espongilito da lagoa de Araré-MS. Anais Encontro Nacional do Talco, Ponta Grossa, 4, 257-281.

[26] Volkmer-Ribeiro, C., Motta, J.F.M. and Callegaro, V.L.M. (1998) Taxonomy and Distribution of Brazilian Spongillites. In: Wanabe, Y. and Fusetani, N., Eds., Sponge Sciences: Multidisciplinary Perspectives, Springer-Verlag, Tokyo, 271278.

[27] Almeida, A.C.S., Volkmer-Ribeiro, C., Varajão, A.F.D.C., Gomes, N.S. and Varajão, C.A.C. (2009) Espículas de esponjas continentais nos sedimentos Cenozóicos do noroeste de Minas Gerais, como indicadores paleoambientais. Revista Brasileira de Paleontologia, 12, 123-138. http://dx.doi.org/10.4072/rbp.2009.2.03

[28] Volkmer-Ribeiro, C., Mansur, M.C.D., Mera, P.A.S. and Ross, S.M. (1998) Biological Indicators in the Aquatic Habitats of the Ilha de Maracá. In: Milliken, W. and Ratter, J., Eds., MARACÁ: The Biodiversity and Environment of an Amazonian Rainforest, John Wiley \& Sons, Chichester, 403-414.

[29] Souza, G.S., Koening, M.L., Leça, E.E. and Coêlho, M.P.C.A. (2007) Diatomáceas indicadoras de paleoambientes do Quaternário de Dois Irmãos, Recife, PE, Brasil. Acta Botanica Brasilica, 21, 521-529. http://dx.doi.org/10.1590/S0102-33062007000300002

[30] Hilgen, F. and Krijgsman, W. (1999) Cyclostratigraphy and Astrochronology of the Tripoli Diatomite Formation (PreEvaporite Messinian, Sicily, Italy). Terra Nova, 11, 16-22. http://dx.doi.org/10.1046/j.1365-3121.1999.00221.x

[31] Machado, V.S., Volkmer-Ribeiro, C. and Iannuzzi, R. (2012) Inventory of the Sponge Fauna of the Cemitério Paleolake, Catalão, Goiás, Brazil. Anais da Academia Brasileira de Ciências, 84, 17-34. http://dx.doi.org/10.1590/S0001-37652012000100004

[32] Machado, V.S., Volkmer-Ribeiro, C. and Iannuzzi, R. (2013) First Record of Preserved Gemmules of a Pleistocene Assemblage of Freshwater Sponges. Revista Brasileira de Paleontologia, 16, 169-180. http://dx.doi.org/10.4072/rbp.2013.2.01

[33] Volkmer-Ribeiro, C. (1999) Esponjas. In: Joly, C.A. and Bicudo, C.E.M., Eds., Biodiversidade do Estado de São Paulo, Brasil: Síntese do conhecimento ao final do século XX, 4: Invertebrados de água doce, FAPESP, São Paulo, $1-9$.

[34] Machado, V.S., Volkmer-Ribeiro, C. and Iannuzzi, R. Investigation of Freshwater Sponges Spicules Deposits in a Karstic Lake in Brazil. Brazilian Journal of Biology. (unpublished)

[35] Ribeiro, C.C., Brod, J.A., Junqueira-Abrod, T.C., Gaspar, J.C. and Petrinovic, I.A. (2001) Pipes de brecha e atividade magmática explosiva no Complexo Alcalino-carbonatítico de Catalão I, Goiás. Revista Brasileira de Geociências, 31, 417-426.

[36] Gibson, S.A., Thompson, R.N., Leonardos, O.H., Dickin, A.P. and Mitchell, J.G. (1995) The Late Cretaceous Impact of the Trindade Mantle Plume: Evidence from Large Volume, Mafic, Potassic Magmatism in SE Brazil. Journal of Petrology, 36, 189-229. http://dx.doi.org/10.1093/petrology/36.1.189

[37] Barbosa, E.S.R., Brod, J.A., Junqueira-Brod, T.C., Dantas, E.L., Cordeiro, P.F.O. and Gomide, C.S. (2012) Bebedourite from Its Type Area (Salitre I complex): A Key Petrogenetic Series in the Late-Cretaceous Alto Paranaíba Kamafugite-Carbonatite-Phoscorite Association, Central Brazil. Lithos, 144-145, 56-72. http://dx.doi.org/10.1016/j.lithos.2012.04.013

[38] Volkmer-Ribeiro, C. and Turcq, B. (1996) SEM Analysis of Silicious Spicules of a Freshwater Sponge Indicate Paleoenvironmental Changes. Acta Microscopica, 5, 186-187. 
[39] Wentwort, C.K. (1922) A Scale of Grade and Class Term for Clastic Sediments. Journal of Geology, 30, 377-392.

[40] Krumbein, W.C. (1934) Size Frequency Distribution of Sediments. Journal of Sedimentary Petrology, 4, 65-77.

[41] Krumbein, W.C. and Pettijohn, F.J. (1938) Manual of Sedimentary Petrography. Appleton Century Crofts, New York, 549 p.

[42] Machado, V.S. (2009) Espongofauna do Paleolago Cemitério, Catalão, Goiás. Ph.D. Dissertation Thesis, Universidade Federal do Rio Grande do Sul, Porto Alegre.

[43] Wetzel, R.G. (1975) Limnology. W. B. Sauders Company, Philadelphia, 743 p.

[44] Almeida-Filho, R., Ibanez, D.M. and Miranda, F.P. (2010) Interpretação morfoestrutural com dados SRTM no auxílio à exploração petrolífera: Um exemplo na bacia sedimentar do Amazonas. Revista Brasileira de Geofísica, 28, 89-98. http://dx.doi.org/10.1590/S0102-261X2010000100007

[45] Shotyk, W. (1988) Review of the Inorganic Geochemistry of Peats and Peatland Waters. Earth-Science Reviews, 25, 95-176. http://dx.doi.org/10.1016/0012-8252(88)90067-0

[46] Ezcurra de Drago, I. (1979) Um nuevo gênero sudamericano de esponjas: Corvoheteromeyenia gen. nov. (Porífera Spongillidae). Neotropica, 25, 109-118.

[47] Tavares, M.C.M., Volkmer-Ribeiro, C. and De Rosa-Barbosa, R. (2003) Primeiro registro de Corvoheteromeyenia australis (Bonetto \& Ezcurra de Drago) para o Brasil com chave taxonômica para os poríferos do Parque Estadual Delta do Jacuí, Rio Grande do Sul, Brasil. Revista Brasileira de Zoologia, 20, 169-182. http://dx.doi.org/10.1590/S0101-81752003000200001

[48] Frost, T.M. (1991) Porifera. In: Thorp, J.H. and Covich, A.P., Eds., Ecology and Classification of North American Freshwater Invertebrates, Academic Press, London, 95-124.

[49] Volkmer-Ribeiro, C. and Pauls, S.M. (2000) Esponjas de agua dulce (Porifera: Demospongiae) de Venezuela. Acta Biologica Venezuelica, 2, 1-28.

[50] Volkmer-Ribeiro, C. (1992) The Freshwater Sponges in Some Peat-Bog Ponds in Brazil. Amazoniana, 12, $317-335$.

[51] Martin, L., Absy, M.L., Fournier, M., Mouguiart, P., Sifeddine, A. and Volkmer-Ribeiro, C. (1992) Some Climatic Alterations Recorded in South America during the Last 7000 Years May Be Expounded by Long-Term el niño Like Conditions. In: Ortlieb, L. and Macharé, J., Eds., Paleo Enso Records, Osrtom-Concytec, Lima, 187-192.

[52] Sifeddine, A., Frohlich, F., Fournier, M., Martin, L., Servant, M., Soubiès, F., Turq, B., Suguio, K. and Volkmer-Ribeiro, C. (1994) La sedimentation lacustre indicateur de changements des paleoenvironments aucours des 300.000 dernière années Carajás Amazonie, Brésil. CR Académie Des Sciences, 318, 1645-1652.

[53] Jorgensen, C.B. (1944) On the Spicule Formation of Spongilla lacustris (L.). I. The Dependence of the Spicule-Formation on the Content for Dissolved and Solid Silicic Acid of the Milieu. Det Kongelige Danske Videnskabernes Selskab, 19, 1-45.

[54] Seer, H.J. and Moraes, L.C. (1988) Estudo petrográfico das rochas ígneas alcalinas da região de Lagoa Formosa, MG. Revista Brasileira de Geociências, 18, 134-140.

[55] Almeida, A.C.S., Varajão, A.F.D.C., Gomes, N.S., Varajão, C.A.C. and Volkmer-Ribeiro, C. (2010) Characterization and Origin of Spongillite-Hosting Sediment from João Pinheiro, Minas Gerais, Brazil. Journal of South American Earth Sciences, 29, 439-453. http://dx.doi.org/10.1016/j.jsames.2009.09.006

[56] Berger, A. and Loutre, M.F. (1991) Insolation Values for the Climate of the Last 10 Million Years. Quaternary Science Reviews, 10, 297-317. http://dx.doi.org/10.1016/0277-3791(91)90033-Q 
Scientific Research Publishing (SCIRP) is one of the largest Open Access journal publishers. It is currently publishing more than 200 open access, online, peer-reviewed journals covering a wide range of academic disciplines. SCIRP serves the worldwide academic communities and contributes to the progress and application of science with its publication.

Other selected journals from SCIRP are listed as below. Submit your manuscript to us via either submit@scirp.org or Online Submission Portal.
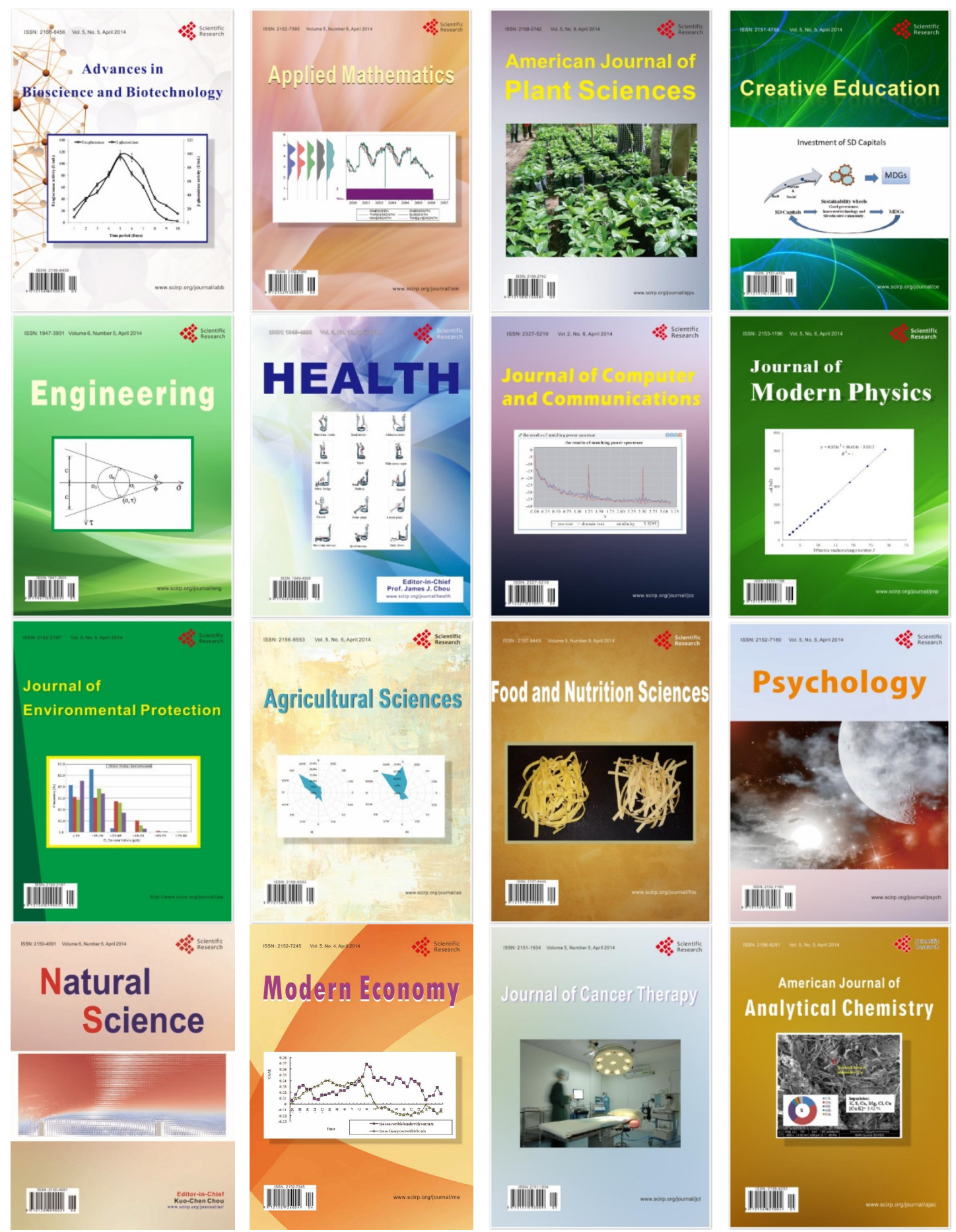